\title{
Expanding the domain of human trafficking research: introduction to the special issue on human trafficking
}

\author{
Edward R. Kleemans
}

Published online: 26 May 2011

(C) The Author(s) 2011. This article is published with open access at Springerlink.com

For a long time, human trafficking research has been trapped into its own dominant victim-oriented perspective. Certainly, nobody will deny that many forms of human trafficking involve serious human rights violations (See for a review: Bales 1999; Lehti and Aromaa 2006; Savona and Stefanizzi 2007; Zhang 2007, 2009; Godziak and Bump 2008; Kleemans 2009; Shelley 2010). However, the various attempts by interest groups, NGOs, and activist researchers to move this issue to the top of political agendas has not been paralleled by sound empirical research into the phenomenon and the accompanying complex interactions between offenders and victims. Briefly, research is still primarily aimed at victims of trafficking - who they are and what makes them vulnerable - and is primarily based on the selection of victims that report to the police and/or are assisted by NGOs (Surtees 2008). Furthermore, research is mainly focused upon the sector where human rights violations are most serious: human trafficking related to the sex industry.

The emotional and ideological arousal of debates on human trafficking seems to cloud several basic findings. First, human trafficking and human smuggling are different phenomena. Human smuggling primarily relates to illegal immigration and the violation of immigration laws and basically involves mutual consent between illegal immigrants, their families, and smugglers. Human trafficking relates to exploitation by the use of force, fraud, coercion or deceit, and most notably refers to forced prostitution or other forms of sexual exploitation, forced labor or services, slavery or practices similar to slavery, servitude, and the removal of internal organs. Human smuggling and human trafficking are two different phenomena, although they share common elements.

Second, because many people confuse human smuggling and human trafficking, the 'Natasha story' is still the dominant focus of public debate: a foreign girl

Guest editor: Edward R. Kleemans

E. R. Kleemans $(\bowtie)$

VU University Amsterdam \& Research and Documentation Centre (WODC), Ministry of Security and Justice, PO Box 20301, $2500 \mathrm{EH}$ The Hague, the Netherlands

e-mail: e.r.kleemans@minjus.nl 
(typically from Eastern Europe) travels to a Western country for work, but ends up as a victim of forced prostitution (Zhang 2009). This prototypical Natasha story denies the fact that many women know that they will work in prostitution (or are already prostitutes in their countries of origin), but are not always aware of the circumstances they will encounter. Furthermore, many women travel voluntarily to Western countries and end up in situations of exploitation only later on. Finally, the Natasha story exaggerates the migration factor in human trafficking: border crossing is not necessary and many victims originate from nearby regions or rural areas (e.g. Lehti and Aromaa 2006).

Third, the victim-oriented perspective simplifies too much the complex interactions between offenders and victims (Kleemans 2009). In many cases, intimate relationships are involved: parents or relatives force children into prostitution, male sexual partners become parasites on the woman's prostitution activities, and traffickers seduce vulnerable girls and move them gradually into (forced) prostitution through a perverted relationship characterized by a combination of grooming, bullying, and violence. The involvement of close, intimate relationships in cases of exploitation explains why free will is a relative phenomenon in this context, why many victims feel reluctant to report to the authorities, and why victims often don't want to be liberated and, after being liberated, may soon return to prostitution. In some ways, cases of human trafficking may be similar to domestic violence, in which victims get trapped into relationships and situations, and have difficulties in breaking away from their oppressors. The principle means of exploitation in human trafficking are manipulation through perverted relationships, close monitoring, intimidation, and outright violence. Implied and actual violence is common and ever present, but may be integrated in complex, personal relationships and (economic) dependency situations.

Fourth, human trafficking research is mainly focused upon the sex industry. However, victims of human trafficking are also found in a variety of other sectors, most notably employment sectors that require large numbers of low-paid, flexible, seasonal workers, sometimes in difficult and dangerous conditions. Also in these sectors, victims may experience debt bondage, withholding of identity documents, threats and abuse, reduced or no pay, excessive working hours, dangerous working conditions, poor accommodation, and discrimination (for a literature review, see Dowling et al. 2007). Nevertheless, little empirical research is focused upon other sectors than the sex industry.

The basic idea behind this special issue of Trends in Organized Crime is to expand the domain of human trafficking research by incorporating topics that are rarely researched. Most of the papers in this special issue were presented during conferences that were organized by the International Research Network on Organized Crime. ${ }^{1}$

\footnotetext{
${ }^{1}$ This research network was founded in 2008 by the German Bundeskrimalamt (BKA), the Research and Documentation Centre (WODC) of the Dutch Ministry of Security and Justice, the Dutch Police Academy and the Home Office (UK), and was joined in 2009 by the Swedish National Council for Crime Prevention (Brå). The network is co-financed by the European Union in the context of the Internal Security (ISEC) programme 'Prevention and Fight against Crime'. The articles in this special issue, except the paper by Petrunov, were presented and discussed during conferences in Frankfurt in 2009 and 2010, and subsequently subjected to the regular peer review process of Trends in Organized Crime.
} 
The first paper by Korsell, Vesterhav and Skinnari focuses upon the specific character of human trafficking, as it compares trafficking in women for the purpose of sexual exploitation with trafficking in drugs. Both sexual services and drugs are sold in local markets, but the logistics are fairly different. Based upon reviews of preliminary investigations and interviews, the authors describe similarities and differences in the phases of purchase (drugs) and recruitment (women), transport and smuggling, and distribution or procuring on local markets. One of the main differences is that drugs should be sold as quickly as possible, whereas human trafficking is a very labor intensive process, and requires a lot of investments in contacts with prostitutes, in monitoring, and in attracting clients. It is important to note that this research was carried out in Sweden, where the purchase of sexual services is illegal.

The second paper by Helfferich, Kavemann and Rabe, is based upon a study commissioned by the German Bundeskriminalamt (BKA). The paper focuses upon victims of human trafficking and the determinants of their willingness to make a statement. To find out why some women make a statement and why others do not, the authors have interviewed three groups of women: women who had made a statement, women who were known to the police but made no statement, and women without contacts with the police. Determinants could be grouped into four major categories: offender strategies, determinants associated with the police and police action, personal factors (e.g. migration objectives and attitude towards prostitution), and frameworks (e.g. legal status and lack of knowledge of language and law). It turned out that no single determinant could by itself predict the willingness or reluctance to make a statement. Therefore, the authors use the concept of a 'shared space of action': a social space, constituted by personal encounters of participants or actors (in this case: police officers and victims), which provides the basis for 'coproduction' that results in a willingness or unwillingness to make a statement. The authors stress that the context is relevant in explaining different outcomes: sometimes violence hinders victims to make a statement, sometimes an act of violence produces both a police contact and an opportunity for a victim to break away from a violent relationship (and perceive it differently for a brief period of time). Furthermore, police checks often are not marked as relevant to make victims reveal themselves, but taking prostitutes without a legal residence status to the police station, spatially removing them from the offender system, may provide an opportunity for them to disclose their history. The context and the interaction between police, victim, and offender, is very relevant in explaining why some victims make a statement and why others do not.

The third article by Verhoeven and Van Gestel explores human trafficking and criminal investigation strategies in the Amsterdam Red Light District (The Netherlands). As human trafficking is a complex crime with several specific characteristics, it poses various challenges for police investigations. Based upon close study of four large scale police investigations into human trafficking, the authors distinguish between four different investigative strategies: focusing respectively on public nuisance (created by procurers), victim statements (and contacts with victims), evidence against the criminal organization (based e.g. on wiretaps), and evidence concerning the exploitation of prostitutes. Comparing these four strategies, the authors consider the consequences of each strategy for the course 
of the investigation and the prosecution and what dilemmas are to be faced. Some choices entail great opportunities or risks, e.g. choices regarding whether or not to involve local investigative police agents or the choice for brief or long run investigations. The article clarifies that the intertwinement of victims, offenders, and situations, creates several dilemmas and path dependencies.

The fourth article by Petrunov focuses on the money acquired from human trafficking, from Bulgaria to Western Europe. It is based upon 152 interviews with prostituted persons (men, women, and transgender persons), traffickers, NGO experts, and representatives of government institutions. If exploitation is central to human trafficking, profits and the distribution of profits may reveal a lot of interesting things. Petrunov concludes that prostitutes receive between $0 \%$ and $50 \%$ of the money they have earned, and most often only between $10 \%$ and $30 \%$. The rest of the money is distributed between various other actors, whereby the top levels receive the largest share and subsequently become involved in money laundering schemes. The study also reveals that Bulgarian traffickers rarely use complex money laundering schemes, most often because they do not fear prosecution.

The last article by Smit explores human trafficking outside the sex industry. In certain economic sectors more victims of labor exploitation have been found than in others, most notably: construction, agriculture, textile and garments, restaurants and catering services, and domestic work and care. The article focuses upon the situation in the Netherlands, where - as in many other countries - the legal framework of trafficking has been extended from trafficking for the purpose of sexual exploitation to other forms of exploitation outside the sex industry. The author describes victims, exploitative conditions, perpetrators, and the difficulties in investigating and prosecuting trafficking cases. Until the end of 2009, 21 cases of exploitation outside the sex industry have been prosecuted and only three resulted in a conviction for trafficking. Problematic is the open ended legal framework and the fact that judges often rule that perpetrators did not take the initiative to recruit, victims are free to walk away, or that situations are not excessive. These results are similar to findings in other countries, where prosecutions and convictions for these types of trafficking are also scarce. The last article shows that opinions vary substantially about how harsh labor conditions and restrictions on free will should be to warrant considering certain exploitative situations as forms of human trafficking. However, research also shows that, in the context of human trafficking, free will is a very relative concept.

Open Access This article is distributed under the terms of the Creative Commons Attribution Noncommercial License which permits any noncommercial use, distribution, and reproduction in any medium, provided the original author(s) and source are credited.

\section{References}

Bales K (1999) Disposable people: new slavery in the global economy. University of California Press, Berkeley

Dowling S, Moreton K, Wright L (2007). Trafficking for the purposes of labour exploitation: a literature review. Home Office Online Report 10/07. Home Office, London. 
Godziak EM, Bump MN (2008) Data and research on human trafficking: bibliography of research-based literature. Institute for the study of international migration, Washington DC

Kleemans ER (2009) Human smuggling and human trafficking. In: Tonry M (ed) Oxford handbook on crime and public policy. Oxford University Press, Oxford, pp 409-427

Lehti M, Aromaa K (2006) Trafficking for sexual exploitation. In: Tonry M (ed) Crime and justice: a review of research, vol. 34. University of Chicago Press, Chicago, pp 133-227

Savona EU, Stefanizzi S (2007) Measuring human trafficking: complexities and pitfalls. Springer, New York Shelley L (2010) Human trafficking: a global perspective. Cambridge University Press, Cambridge

Surtees R (2008) Traffickers and trafficking in South and Eastern Europe: considering the other side of human trafficking. Eur J Crim 5(1):39-68

Zhang SX (2007) Smuggling and trafficking in human beings: all roads lead to America. Prager, Westport, CT

Zhang SX (2009) Beyond the 'Natasha' story - a review and critique of current research on sex trafficking. Glob Crim 10(3):178-195 